\title{
Gender Inequalities in Academic Achievement among Internally Displaced children in Colombia
}

\author{
Adriana Carolina Silva-Arias, Ph.D. \\ Universidad Militar Nueva Granada, Colombia* \\ Jaime Andrés Sarmiento-Espinel, Ph.D. \\ Universidad Militar Nueva Granada, Colombia**
}

Laura Victoria González-Cogollos, Mg.

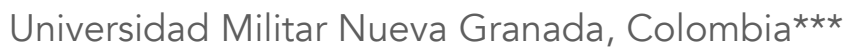

\begin{abstract}
Using 2015 data of the Colombia Demographic and Health Survey, we investigated the incidence of belonging to a household with an Internally Displaced Person (IDP) on the likelihood of grade retention by sex. Particularly, a bivariate logistic regression was used to identify the correlation between families with IDP and children's gender on the probability of repeating a school year. Boys' were negatively affected when they live in an IDP household. Also, boys had a higher likelihood of repeating a grade. We need to know how to act upon the social determinants that create social gaps and disadvantages across IDP, but also, to align with Sustainable Development Goals to eliminate gender inequalities.
\end{abstract}

\section{Keywords}

Academic Failure, Grade Repetition, Violence, armed conflicts, gender roles, civil war, Disadvantaged groups, Displaced Persons, War Victims.

\section{Thesaurus}

Unesco Thesaurus, Social Sciences.

\section{Para citar este artículo}

Silva-Arias, A. C., Sarmiento-Espinel, J. A., \& González-Cogollos, L. V. (2020). Gender Inequalities in Academic Achievement among Internally Displaced children in Colombia. Revista Latinoamericana de Ciencias Sociales, Niñez y Juventud, 18(2), 1-19. http://dx.doi.org/10.11600/1692715x.18213

\section{Historial}

Recibido: 28.01.2020

Aceptado: 20.04.2020

Publicado: 08.06.2020

Información artículo

Este artículo es producto del proyecto «Incidencia del conflicto armado en la educación de los colombianos», financiado por la Vicerrectoría de Investigaciones de la Universidad Militar Nueva Granada con código INV-ECO-2324, vigencia 2017. Esta investigación fue realizada entre febrero de 2017 y febrero de 2018. Área: Economía y Negocios. Subárea:

Economía 


\section{Desigualdades de género en el desempeño académico de los niños desplazados forzados en Colombia}

Resumen (analítico)

Utilizando datos de 2015 de la Encuesta de Demografía y de Salud de Colombia investigamos la incidencia de pertenecer a un hogar con una persona desplazada forzada por el conflicto armado interno (IDP) sobre la probabilidad de repetición de grado por sexo. En particular, se utilizó una regresión logística bivariada para identificar la correlación entre familias con desplazados internos y el género de los niños en la probabilidad de repetir un año escolar. Los niños se vieron afectados negativamente cuando vivieron en un hogar desplazado forzado. Además, los varones tuvieron una mayor probabilidad de repetir una asignatura. Necesitamos saber cómo actuar sobre los determinantes sociales que crean brechas sociales y desventajas entre los desplazados internos, pero también para alinearnos con los objetivos de desarrollo sostenible en busca de eliminar las desigualdades de género.

Palabras clave

Rendimiento Escolar, Repetición, Violencia, Conflictos Armados, Roles de Género, Guerra Civil, Grupo Vulnerable, Personas Desplazadas, Víctima de Guerra.

\section{Desigualdades de gênero no desempenho acadêmico de crianças deslocadas forçadas na Colômbia}

Resumo (analítico)

Utilizando dados de 2015 da Pesquisa Demográfica e de Saúde da Colômbia (DHS), investigamos a incidência de pertencer a uma família com uma Pessoa Deslocada Interna (IDP) sobre a probabilidade de retenção de notas por sexo. Particularmente, uma regressão logística bivariada foi usada para identificar a correlação entre famílias com PID e sexo das crianças sobre a probabilidade de repetir um ano escolar. Os meninos foram afetados negativamente quando vivem em uma casa de deslocados internos. Além disso, os meninos tinham maior probabilidade de repetir uma nota. Precisamos saber como agir de acordo com os determinantes sociais que criam lacunas e desvantagens sociais entre os deslocados internos, mas também alinhar com os ODS para eliminar as desigualdades de gênero.

Palavras-chave

Fracasso acadêmico, repetição de notas, violência, conflitos armados, papéis de gênero, guerra civil, grupos desfavorecidos, pessoas deslocadas, vítimas de guerra.

Información autores

[*] Economista de la Universidad del Rosario, Magíster en economía de la Universidad de los Andes, Doctora en estudios de población de El Colegio de México. Profesora Universidad Militar Nueva Granada, Bogotá, Colombia. iD 0000-0003-1610-881X. Índice H5: 8. Correo electrónico: adriana.silva@unimilitar.edu.co

[**] Economista y Magíster en economía de la Universidad Javeriana, Doctor en economía de El Colegio de México. Profesor Universidad Militar Nueva Granada, Bogotá, Colombia. iD 0000-0002-1945-6054. Índice H5:

6. Correo electrónico: jaime.sarmiento@unimilitar.edu.co

[***] Economista de la Universidad Militar Nueva Granada, Magíster en política social de la Universidad Javeriana. Joven investigadora Universidad Militar Nueva Granada, Bogotá, Colombia. (iD) 0000-0002-7876-724X. Índice H5: 1. Correo electrónico: asistente2.gesma@unimilitar.edu.co 


\section{Introduction}

$\Upsilon \begin{aligned} & \text { here is a long history of armed conflict in Colombia. Since the late } 1940 \text { s, there } \\ & \text { were confrontations between two political wings and tension between pea- }\end{aligned}$ sants and landowners. This period of approximately ten-year internal conflict is known as La Violencia. Despite the signing in 1958 of a coalition between the two political parties to alternate the government, violence persisted. The arisen of left-wing guerrillas and right-wing paramilitary groups brought a new armed conflict. In the early 1980 , criminal groups associated with drug production and distribution led to an increase in violence within cartels and terrorism acts to persuade the Colombian government. As a consequence of these confrontations, civilian victims increased considerably during this period (Ibáñez \& Moya, 2010; Moya \& Carter, 2019).

Since then, the dynamics of the armed conflict in Colombia has marked by three events. In 2006, paramilitary groups started a process of disbanding and disarming. However, new armed factions began to fight for the control of some zones formerly under paramilitary control. In 2016, the largest and oldest guerrilla group in the hemisphere, the Revolutionary Armed Forces of Colombia (Farc), signed a peace agreement and started its demobilization (Internal Displacement Monitoring Centre [IDMC], 202O; Moya \& Carter, 2019).

During many stages of the Colombian armed conflict, armed groups have been used violence against civilians as a deliberate strategy to gain control of disputed areas and spread terror among the population (Prada, 2016). Indeed, more than 8.5 million civilians have been victims of the armed conflict since 1985 , including 5.6 million internally displaced persons until 2019 (Gottwald, 2016; IDMC, 2020).

Armed conflict can cause long-lasting damages. It has generated irreversible consequences on the population (Andrade et al., 2015; Buvinić et al., 2013). There is scarce literature about the armed conflict impacts on household well-being (Kadir et al., 2019). Part of this is due to the complex and multi-dimensional effects of the armed conflict, 
which becomes an obstacle to sustainable development and human security (United Nations Development Programme \& World Health Organization, 2005).

Civil war negatively affects educational outcomes (Bohada, 2010; Brück et al., 2019). Boys and girls from households with Internally Displaced Persons (IDPs) have been the most vulnerable to the effects of armed conflict on educational achievement (Brown \& Velásquez, 2017; Buvinić et al., 2013). Children from displaced households had not academically performed as well as other students (Akresh \& De Walque, 20o8; Gimenez \& Barrado, 2020; Kadir et al., 2019).

The impact of forced displacement is evidenced in the quality of life of household members, generating a negative context for their educational processes (Avendaño-Villa et al., 2015; Gimenez \& Barrado, 2020). There are factors associated with forced displacement, such as household poverty, which generate direct consequences on the academic performance of students (Bernardo \& Baranovich, 2014; Navarrete et al., 2017). For example, Ordóñez (2009) found that the nutritional deficiencies of IDP's households affected the school development of children.

Also, the discrimination that boys and girls have been suffering in school for being a member of an internally displaced household can be so pervasive as to limit their academic attainment (Bertoni et al., 2019; Mooney \& French, 2005). Boys and girls from IDP households are repeatedly absent from school, more than other children (Ibáñez, 20o6; Munevar et al., 2019). They often miss school because their labor is needed at home or to generate income for households' economic survival (Ibáñez \& Querubín, 2004).

Forced displacement is a traumatic event for household members. Many victims of forced displacement have suffered double or triple displacements, and it was more prevalent for IDPs belonging to ethnic groups. It could affect their physical and psychological health, which also could affect children's academic achievement (Mancini, 2020). The effects on the victims' mental health of the armed conflict can cause disruptions in different dimensions of the household' members, such as children's education development (Kecmanovic, 2012; Manrique-Palacio et al., 2018; Rodriguez et al., 2006).

The intersectionality of IDPs' disadvantages is a crucial category to understand educational inequalities. Depending on the context, the magnitude of the disruption frequently varies between boys and girls (Buvinić et al., 2013; Hattar-Pollara, 2019; Sutanuka \& Prakarsh, 2016). Studies that analyze the relation between children's education outcomes and the presence of an IDP in a household are scarce. Still, the literature is more 
scarce if gender is also considered. Boys and girls run a different risk of suffering different consequences in their educational outcomes for being part of a family forced displaced by armed conflict (Contreras et al., 2012).

Why might grade retention be different for girls and boys from IDP's households? Some literature has evidenced that boys could achieve lower outcomes than girls on various non-cognitive dimensions. Boys could have attention and behavioral difficulties. Boys' levels of inhibitory control and perceptual sensitivity are lower than girls'. Boys are less able to delay gratification, and more likely to be diagnosed with attention deficit and hyperactivity disorder (Autor et al., 2019; Bertrand \& Pan, 2013; Brenøe \& Lundberg, 2018; Kadir et al., 2019).

Besides, the behavior of boys is more responsive than girls to other indicators of disadvantage, such as forced displacement households, poor-quality schools, and less-educated neighborhood (Bertrand \& Pan, 2013; Brenøe \& Lundberg, 2018; Lei \& Lundberg, 2020). Within the possible explanations for this gender gaps, one could be that family circumstances and parental time dedication could affect more boys' academic outcomes than girls', or because low-socioeconomic status households invest relatively more in girls than in boys (Autor et al., 2019; Autor et al., 2016).

Also, a family disadvantage, such as being part of an IDP household, can strengthen the negative effect that neighborhoods and schools have on boys' academic outcomes. Male children may be more exposed to violence in recipient communities and educational institutions. In some scenarios, authority figures could be more severe with boys than with girls; perhaps boys affront greater disciplinary and criminal sanctions from teachers and police (Autor et al., 2019, 2016).

What we seek to understand is whether belonging to a household victim of the Colombian armed conflict impacts boys and girls equally or if it exacerbates gender educational disparities in a society affected by it. Among the possible measures of educational outcomes, we considered school retention to analyze the case of Colombian boys and girls from IDP's households.

This educational outcome could be another source of discrimination. Evidence demonstrates that grade repetition is not adequate for most students; in some cases, it could worsen the student's subsequent academic achievement instead of improving it (Lorence, 2014). Besides, repeaters' self-esteem could be negatively affected because of 
their age difference with their same-grade peers (Kamal \& Bener, 2009). Older students have a higher probability of report health problems (Needham et al., 2004).

This research analyzed the link between grade repetition and being a boy or a girl in a household with any victim of armed conflict. The empirical approach used 2015 Demographic and Health Surveys data from Colombia, as the country with the most significant number of IDPs worldwide: 7.4 million, $15 \%$ of the Colombian population, $18 \%$ of worldwide IDPs in 2019 (IDMC, 2020; Unidad para la Atención y Reparación Integral a las Víctimas, 2019).

Specifically, our research question is: Did forced displacement affect the repetition rate of Colombian girls and boys? With this purpose based on the 2015 DHS data and through logistic regressions, we estimated the net effect of forced displacement on the probability of repeating a grade for boys and girls.

We extended prior research in two aspects. First, we studied the relation between grade retention and one of the principal consequences of armed conflict, forced displacement. Second, we estimated the net effect of being a boy or a girl from an IDP household on the probability of failing a grade.

\section{Methodology}

\section{Data Sources}

We used the 2015 Colombia Demographic and Health Surveys (DHS), which is a multinational survey that tracks population health in developing countries. In the Colombian case, DHS is a population-based survey of the Ministerio de Salud y Protección Social (Ministry of Health and Social Protection) and Colombian Association for Wellbeing and Family (Profamilia by its acronym in Spanish). Data is publicly available at https://www.dhsprogram.com/Data/

DHS surveys are rich in information about a wide range of topics, from a representative population-based sample. The information collected during the study covered all the Sustainable Development Goals (SDGs). Questionnaires include living conditions and demographic situation in the country. Colombian DHS survey contains questions that collect data relevant to identify IDPs households. This type of data could also serve as input to evaluate the country's National Development Plan progress. 
The 2015 Colombian DHS has information about 44614 Colombian households. The survey interviewed a total of 52479 women between 13 and 59 years old, and 40300 men between 13 and 69 years old. ${ }^{1}$

Besides, we added to each household reported in the 2015 DHS database, the corresponding municipal index of IDPs. This variable is the ratio between the number of IDPs arriving in a municipality and its population per thousand inhabitants. ${ }^{2}$ These records came from the Unidad para la Atención y Reparación Integral a las Víctimas, which is the official entity for attention, assistance, and integral reparation of Colombian armed conflict victims. The data source for each municipality population came from the website of the National Administrative Department of Statistics (Dane for its acronym in Spanish).

\section{Variables}

Our universe of the study was a sample of Colombian girls and boys of school-age (6 to 15 years old). According to Colombian law, a child begins formal education at the age of five, and the limit for compulsory education is at the age of 15 years old. Under normal conditions, a boy or a girl who is 15 years old should have completed primary school and should have completed four years of high school.

We measure the impact of belonging to a household with at least one IDP member in the school repetition rate, as one measure of academic achievement and the adaptability of boys and girls belonging to households victims of armed conflict. Our explanatory variable of interest is a dummy variable that classifies a household as IDP if at least one member has migrated due to the Colombian armed conflict. We also had included as controls some available variables at the individual, household, and community level: age, characteristics of the household head (sex, age, and educational level), household wealth index, household geographical region and municipal index of IDPs.

We used a logistic regression model to estimate the partial effect of forced displacement on the probability of repeating a grade for boys and girls. The estimated model is as follows:

${ }^{1}$ Details of the methodology and survey report are available online at https://profamilia.org.co/investigaciones/ends/

2 The number of IDPs at the municipal level is publicly available from the Register of Victims of the Government in Colombia (RUV by its acronym in Spanish) at https://www.unidadvictimas.gov.co/es/ reportes 


$$
\begin{aligned}
Y_{i}^{*}= & \beta_{0}+\delta_{0} \text { Female }+\beta_{1} I D P_{h h}+\delta_{1} \text { Female }^{*} I D P_{h h}+\beta_{2} X_{\text {ind }}+\delta_{2} \text { Female }^{*} X_{\text {ind }} \\
& +\beta_{3} X_{h h}+\delta_{3} \text { Female }^{*} X_{h h}+B_{4} X_{\text {cont }}+\delta_{4} \text { Female }^{*} X_{\text {cont }}+\varepsilon_{i},
\end{aligned}
$$

In our notation, $Y_{i}^{*}$ denotes the dependent variable of repeating a grade. The variable Female is a dummy variable that is one when the child is a girl and zero when the child is a boy. The variable $I D P_{h h}$ is a dummy variable that identifies the forced displacement of any member of the household. We also include the characteristics of boys and girls at individual $\left(X_{\text {ind }}\right)$, household $\left(X_{h h}\right)$, and context $\left(X_{\text {cont }}\right)$ levels. Because we considered that the effect of all the explanatory variables differs across boys and girls, we specify model (1) so the intercept and all slopes can be different depending on the sex of the child (see $\delta$ coefficients).

\section{Data Analysis}

Table 1 shows the descriptive statistics of repeating a grade of our sample of children by sex. Approximately $9 \%$ of boys and $7 \%$ of girls fail a class. Also, $1 \%$ of boys and girls belong to households where at least one of their members was an IDP.

The educational level of the household head was mainly primary, closely followed by secondary. The highest proportion of households was in the lowest quintile of the wealth index (about 47\%), which was related to the educational level of the household head. The majority of the households in the sample belong to the Atlantic region. The mean municipal index of IDPs (nominal pressure index) was six; there were approximately six IDPs per 1000 inhabitants at the municipality level.

\section{Ethical Issues}

Our primary source of information came from the Demographic and Health Survey (DHS) Project. This program collects information in over go countries. DHS has been one of the most recognized public sources of representative data on themes such as child health and nutrition, family planning, among others.

The DHS World Surveys maintain strict standards to anonymize respondents' information. Also, each interview was conducted only with informed consent. On the other hand, the Institutional Review Board has reviewed the procedures and questionnaires of each country as well as legislation of the nation in which it is applied (Ministerio de Salud y Protección Social \& Profamilia, 2015). 


\section{Table 1}

Descriptive Statistics by Sex

\begin{tabular}{|c|c|c|}
\hline Variable & Boys & Girls \\
\hline \multicolumn{3}{|l|}{ Grade Repetition } \\
\hline No repeating & 0.905 & 0.928 \\
\hline Repeating & 0.095 & 0.072 \\
\hline \multirow[t]{2}{*}{ Age } & 10.524 & 10.566 \\
\hline & $(2.904)$ & $(2.877)$ \\
\hline \multirow[t]{2}{*}{ Age $\mathrm{HH}$} & 45.301 & 45.092 \\
\hline & (12.906) & (12.610) \\
\hline \multicolumn{3}{|l|}{ Sex HH } \\
\hline Male & 0.645 & 0.637 \\
\hline Female & 0.355 & 0.363 \\
\hline \multicolumn{3}{|l|}{ Education $\mathrm{HH}$} \\
\hline No education & 0.069 & 0.071 \\
\hline Primary & 0.380 & 0.364 \\
\hline Secondary & 0.359 & 0.372 \\
\hline Tertiary & 0.192 & 0.193 \\
\hline \multicolumn{3}{|l|}{ IDPs Household } \\
\hline None IDP in Household & 0.989 & 0.988 \\
\hline IDPs in Household & 0.011 & 0.012 \\
\hline \multicolumn{3}{|l|}{ Wealth Index } \\
\hline Poorer & 0.473 & 0.467 \\
\hline Middle & 0.189 & 0.200 \\
\hline Richer & 0.338 & 0.332 \\
\hline \multicolumn{3}{|l|}{ Region } \\
\hline Atlántica & 0.253 & 0.250 \\
\hline Oriental & 0.176 & 0.171 \\
\hline Central & 0.229 & 0.228 \\
\hline Pacífica & 0.172 & 0.173 \\
\hline Bogotá & 0.141 & 0.148 \\
\hline Orinoquía/Amazonía & 0.029 & 0.030 \\
\hline Municipal Index of IDPs & 6.555 & 6.187 \\
\hline No. Observations & 15009 & 14636 \\
\hline
\end{tabular}

Note. Data sources: Colombian DHS (2015), RUV, Dane. Standard Deviation in parenthesis. 


\section{Results}

Based on the methodological strategy previously described, we focus on grade repetition as a measure of educational achievement. Table 2 presents the results of the estimating model (1).

Table 2

Logistic Regression Results

\begin{tabular}{|c|c|c|c|c|c|}
\hline Explanatory Variables & Coefficien & & Explanatory Variables & Coefficient & \\
\hline \multirow[t]{2}{*}{ Female } & 2.132 & $\star \star$ & Middle & 0.008 & \\
\hline & $(0.921)$ & & & $(0.107)$ & \\
\hline \multirow[t]{2}{*}{ Age } & -1.057 & $\star \star \star *$ & Richer & -0.053 & \\
\hline & $(0.133)$ & & & $(0.113)$ & \\
\hline \multirow[t]{2}{*}{ Female * Age } & -0.408 & $\star *$ & Female * Middle & 0.064 & \\
\hline & $(0.169)$ & & & $(0.172)$ & \\
\hline \multirow[t]{2}{*}{ Age Squared } & 0.049 & 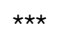 & Female * Richer & -0.207 & \\
\hline & $(0.006)$ & & & $(0.190)$ & \\
\hline \multirow[t]{2}{*}{ Female * Age Squared } & 0.018 & $\star \star$ & Region (Ref. Atlántica) & & \\
\hline & $(0.008)$ & & Oriental & -0.194 & \\
\hline \multirow[t]{2}{*}{ Age $\mathrm{HH}$} & -0.005 & & & $(0.119)$ & \\
\hline & $(0.003)$ & & Central & 0.090 & \\
\hline \multirow[t]{2}{*}{ Female * Age HH } & -0.007 & & & $(0.105)$ & \\
\hline & $(0.005)$ & & Pacífica & -0.022 & \\
\hline \multirow[t]{2}{*}{ Female HH (Ref. Male) } & 0.209 & $\star \star$ & & $(0.122)$ & \\
\hline & $(0.092)$ & & Bogotá & -0.112 & \\
\hline \multirow[t]{2}{*}{ Female * Female HH } & -0.300 & $\star *$ & & $(0.220)$ & \\
\hline & $(0.126)$ & & Orinoquía/Amazonía & -0.106 & \\
\hline Education HH (Ref. No Education) & & & & $(0.174)$ & \\
\hline \multirow[t]{2}{*}{ Primary } & -0.299 & * & Female * Oriental & 0.350 & ** \\
\hline & $(0.153)$ & & & $(0.175)$ & \\
\hline \multirow[t]{2}{*}{ Secondary } & -0.645 & $\star \star *$ & Female ${ }^{*}$ Central & 0.172 & \\
\hline & $(0.168)$ & & & (0.149) & \\
\hline \multirow[t]{2}{*}{ Tertiary } & -0.757 & 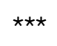 & Female * Pacífica & 0.261 & \\
\hline & $(0.233)$ & & & $(0.250)$ & \\
\hline \multirow[t]{2}{*}{ Female * Primary } & -0.213 & & Female * Bogotá & 0.399 & * \\
\hline & $(0.207)$ & & & $(0.220)$ & \\
\hline \multirow[t]{2}{*}{ Female * Secondary } & 0.074 & & Orinoquía/Amazonía & 0.448 & * \\
\hline & $(0.223)$ & & & $(0.246)$ & \\
\hline \multirow[t]{2}{*}{ Female * Tertiary } & -0.239 & & Municipal Index of IDPs & 0.004 & ** \\
\hline & $(0.368)$ & & & $(0.002)$ & \\
\hline \multirow[t]{2}{*}{ IDPs Household } & 0.574 & ** & Female * Municipal Index of IDPs & -0.002 & \\
\hline & $(0.278)$ & & & $(0.003)$ & \\
\hline \multirow[t]{2}{*}{ Female * IDPs Household } & -0.484 & & Intercept & 3.645 & 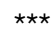 \\
\hline & $(0.471)$ & & & $(0.696)$ & \\
\hline \multicolumn{6}{|l|}{ Wealth index (Ref. Poorer) } \\
\hline & & & No. Observations & 29645 & \\
\hline
\end{tabular}

Note. Data sources: Colombia DHS 2015, RUV, Dane. Robust standard errors in parenthesis. ${ }^{*} p<0.1,{ }^{* *} p<0.05$, *** $p<0.01$ 
We estimate the effect of forced displacement and gender condition on the probability of repeating a school year (Table 3). First, our empirical strategy identified whether there was a difference in the likelihood of repeating a school grade of children belonging to IDP households, as compared to families that did not have. At the same time, we considered other covariates in the characteristics of a typical boy and girl in the sample. There was an increment of $6 \%$ in the expected probability of repeating a grade if a Colombian boy was a member of an IDP household. This increase due to the forced displacement condition was statistically significant at $10 \%$. Therefore, we reject the null hypothesis that being part of a forcibly displaced household did not affect the probability of repeating a grade.

After controlling for all other independent variables, there is at most a $10 \%$ probability that the effect of being forcibly displaced on the expected likelihood of repeating a grade was the result of chance. However, in the case of girls from an IDP household, this effect was not statistically significant. The probability of repeating a grade increased 0.5 percentage points, but it could be due to chance; there was no statistical evidence that the IDP condition affected girls' school repetition.

\section{Table 3}

\section{Selected Marginal Effects on Grade Repetition Probability}

\begin{tabular}{|c|c|c|}
\hline Effect & Coefficient & \\
\hline \multicolumn{3}{|c|}{ Gap between IDPs and non-IDPs household } \\
\hline \multirow[t]{2}{*}{ Male } & 0.060 & * \\
\hline & $(0.037)$ & \\
\hline \multirow[t]{2}{*}{ Female } & 0.005 & \\
\hline & $(0.023)$ & \\
\hline \multicolumn{3}{|c|}{ Gap between Female and Male } \\
\hline \multirow[t]{2}{*}{ IDPs Household } & -0.032 & ** \\
\hline & $(0.015)$ & \\
\hline \multirow[t]{2}{*}{ Non-IDPs Household } & -0.087 & * \\
\hline & $(0.048)$ & \\
\hline
\end{tabular}

Note. Data sources: Colombia DHS 2015, RUV, Dane. Robust standard errors in parenthesis. *p<0.1, **p< $<0.05$, **** $p<0.01$

Second, the grade repetition probability difference between boys and girls students is negative in both scenarios of the presence and absence of IDPs in the household. The 
more considerable gap of gender is for non-IDPs; it is about $8.7 \%$ less likely to repeat a grade for a girl than for a boy. That is a sizable as well as a significant difference. Among the households with victims of the armed conflict, girls had 3.2 percentage points less probability of failing a grade than boys in the same situation. Reviewing, although Colombian girls were less likely to repeat a grade, girls' advantage was lower when they were from IDP households.

\section{Discussion}

Regarding the answer to our research question, we estimate that the probability of repeating a school grade of boys belonging to internally displaced households did increase by $6 \%$. In the case of girls belonging to internally displaced families, the probability of repeating a grade increased the retention rate by $0.5 \%$. However, there was no statistical evidence that this increase significantly affected IDP girls' school repetition.

Colombia has the most significant number of boys and girls belonging to households with IDPs worldwide. Children from IDPs' homes were 2 million until 2017 (Save the Children, 2018). The proportion of forced displaced youth who were still in primary school was almost double that of the non-displaced. The above indicates a delay in admission and more repetition among children in internally displaced households (Ferris \& Winthrop, 2010). Our findings are consistent with the literature, which reported that girls had better chances of completing school grades than boys in a family disadvantage circumstances as IDPs households (Autor et al., 2019; Autor et al., 2016; Bertrand \& Pan, 2013; Brenøe \& Lundberg, 2018; Lei \& Lundberg, 2020; Schneider, 2020).

However, forced displacement due to violence also generated a negative impact on the educational trajectory of Colombian girls, since the advantage of girls concerning boys decrease in 5.5 percentage points when we compare IDP households with non-IDP households. Colombian armed conflict has been reinforcing the inequalities that trap countries in cycles of violence.

Also, it is relevant to review the budget of the education sector. According to data of World Development Indicators, during 2018, the percentage of Colombian GDP dedicated to education was $4.1 \%$, while the proportion of military expenditure was $3.2 \%$. An indirect effect of Colombian armed conflict has been prioritizing, in some sense, the military instead of education spending. The government and donors should prioritize 
the development of an inclusive education system. It is relevant because education acts as a force for peace and gender equity (United Nations Educational Scientific and Cultural Organization [Unesco], 2011).

Some interventions could be useful in rebuilding education achievement for children from households with victims of armed conflict context. It is necessary to ensure that all critical national education system's mechanisms consider policies specifically for boys and girls from IDPs' households and recognize how gender affects their educational trajectory.

Mainly, the key is to implement a gender-responsive education plan for armed conflict victims. Public funds allocation could play a crucial part in narrowing learning gaps. Funding is relevant, among others, to implement a specific training and recruiting process for teachers in the municipalities with a higher prevalence of IDPs. It is necessary to attract qualified teachers and give them adequate support for promoting gender equity and inclusive education for boys and girls from households with victims of armed conflict. It is also relevant to avoid teacher and student absenteeism through early warnings to protect them in contexts with a high prevalence of armed conflict (Rodríguez \& Sánchez, 2012).

In these contexts, public education should offer additional support for children from households with victims of armed conflict. Among others, it is necessary to introduce mandatory gender training for teachers that have the most contact with boys and girls from IDPs' households. Remedial education programs can also help boys and girls with learning difficulties related to disadvantage families, as the victims of armed conflict.

Also, it is required to introduce mandatory support of student affairs centers in the schools for students that provide advice, information, and support services for boys and girls with lower grades, preventing early grade retention. This support could be formal or informal in addressing specific student needs by household's migration status and gender.

Formal programs could be interventions adhering to established school rules, looking to promote harmony and address students' needs. The informal ways are other types of actions beyond the programmatic approaches established by the education system to calibrate the peculiarities of the students from IDPs households, such as the mediation of disputes among students because their family was armed conflict victim, and more frequent among boys.

The balancing of these efforts would encourage the resilience of these victims of war who generally are also involved in an economic vulnerability context. In effect, a proper 
follow-up could maintain students' possibilities of benefit from the education system. In this sense, our results highlight the vital role of equity in education and gender in contexts with a high intensity of armed conflict such as Colombia.

This study contributes to the growing body of empirical research that analyzes the incidence of armed conflict on children's academic achievement. This paper studied the effect on grade repetition of being a Colombian boy or girl of an IDP household. The purpose of this research refers to propose educational and governmental policy tools to prioritize funding, resources, and efforts to reduce these inequalities. This study is relevant, given the significant influence of armed conflicts on the civilian population, the importance of education for the well-being of boys and girls, and the possible poverty traps among the victims. Also, we analyze the Colombian case because it is the country with the most significant number of children IDPs in the world.

We found evidence that the children from households victims from Colombian armed conflict had more likelihood of grade repetition, especially boys. As shown in our results section, children from homes with IDP members increased the chance in grade retention of boys and girls, but the increase in probability was higher and significant for boys from IDP households. In consequence, the effect of being a child belonging to a family with any member victim from armed conflict on failure a grade becomes a new source of inequality of educational opportunities, especially for boys. When compared to children of the same age, an IDP has a lower accumulation of human capital (Ferris \& Winthrop, 2010).

We present some of the limitations of our study. First, the data is limited to DHS surveys that do not guarantee the representativeness of all forcibly displaced children in Colombia. Second, we define our academic achievement measure as school repetition, leaving aside other indicators of educational attainment such as attendance or results in standardized tests. Third, our sample only considers boys and girls who continued in the education system, leaving aside the children who, due to the armed conflict, could not continue studying.

Our findings support that the Colombian government must guarantee educational policies differentiated by the condition of forced displacement and by sex to ensure adequate school performance. In any case, the State must guarantee the reduction of the armed conflict, which has a significant impact on children's academic performance, as well as compromising their future well-being. Governments bear the primary responsi- 
bility to guarantee a child's right to education; it is necessary to respect and defend it even more in adverse situations.

In the Colombian case, the government has been unable to fulfill that social responsibility, so other actors, such as the international community, must be more involved. It is essential that Unesco and Save the Children monitor the effectiveness of policies and budgets aimed at reducing educational and gender gaps, especially in armed conflict contexts such as the Colombian. Equity education and equity gender in armed conflict contexts must be treated as a distinct and priority concern in all monitoring and reporting activities by UN agencies.

In doing so, researchers must consider analyzing the possible transmission channels to understand the link between gender and armed conflict on educational gaps. Besides, it is needed more research to locate ethnographic gender analyzes within the broader framework of debates shaping the academic understanding of education and gender gaps in diverse armed conflict contexts.

It is relevant to analyze if the educational system has been exacerbated these inequalities in boys and girls that have been exposed to Colombian armed conflict. Future researches could carry out case studies comparing the performance of boys and girls victims of the armed conflict in different types of educational institutions or between IDPs and international refugees. It is also essential to document the existence and effectiveness of educational policy initiatives that focus on the population victim of the armed conflict with a gender vision.

\section{Acknowledgments}

This paper is part of the research project INV-ECO-2324 financed by the Vice Presidency for Research of the Universidad Militar Nueva Granada-2017 term. Research assistance in the initial elaboration of the database by Sandra Munevar is gratefully acknowledged. Also, we appreciate the comments and suggestions of the editors and anonymous reviewers of this journal to improve the paper. 


\section{References}

Akresh, R., \& De Walque, D. (2008, mayo). Armed conflict and schooling: Evidence from the 1994 Rwandan genocide. Policy Research Working Paper, 4606. https://doi.org/ 10.1596/1813-9450-4606

Andrade, J., Zuluaga, C. V., Ramírez, J. J., \& Ramírez, M. A. (2015). Caracterización y motivos para desplazarse en familias víctimas de conflicto armado asentadas en el departamento del Quindío. Pensamiento Americano, 8(15), 13-26.

Autor, D., Figlio, D., Karbownik, K., Roth, J., \& Wasserman, M. (2016). School Quality and the Gender Gap in Educational Achievement. American Economic Review, 106(5), 289-295. https://doi.org/10.1257/aer.p20161074

Autor, D., Figlio, D., Karbownik, K., Roth, J., \& Wasserman, M. (2019). Family disadvantage and the gender gap in behavioral and educational outcomes. American Economic Journal: Applied Economics, 11(3), 338-381. https://doi.org/10.1257/app.20170571

Avendaño-Villa, I., Cortés-Peña, O. F., \& Guerrero-Cuentas, H. (2015). Competencias sociales y tecnologías de la información y la comunicación como factores asociados al desempeño en estudiantes de básica primaria con experiencia de desplazamiento forzado. Diversitas: Perspectivas en Psicología, 11(1), 13-36. https://doi.org/10.15332/ \$1794-9998.2015.0001.01

Bernardo, M. A. C., \& Baranovich, D. L. (2014). Higher education in the heart of armed conflict: The pivotal role of student affairs. International Journal of Educational Development, 35, 78-85. https://doi.org/10.1016/j.ijedudev.2012.08.007

Bertoni, E., Di Maio, M., Molini, V., \& Nistico, R. (2019). Education is forbidden: The effect of the Boko Haram conflict on education in North-East Nigeria. Journal of Development Economics, 141, 1-19. https://doi.org/10.1016/j.jdeveco.2018.06.007

Bertrand, M., \& Pan, J. (2013). The trouble with boys: Social influences and the gender gap in disruptive behavior. American Economic Journal: Applied Economics, 5(1), 32-64. https://doi.org/10.1257/app.5.1.32

Bohada, M. (2010). Desplazamiento forzado y condiciones de vida de las comunidades de destino: el caso de Pasto, Nariño. Revista Economía Institucional, 12(23), 259-298.

Brenøe, A. A., \& Lundberg, S. (2018). Gender gaps in the effects of childhood family environment: Do they persist into adulthood? European Economic Review, 109, 42-62. https://doi.org/10.1016/j.euroecorev.2017.04.004 
Brown, R., \& Velásquez, A. (2017). The effect of violent crime on the human capital accumulation of young adults. Journal of Development Economics, 127, 1-12. https:// doi.org/10.1016/j.jdeveco.2017.02.004

Brück, T., Di Maio, M., \& Miaari, S. H. (2019). Learning the hard way: The effect of violent conflict on student academic achievement. Journal of the European Economic Association, 17 (5), 1502-1537. https://doi.org/10.1093/jeea/jvyo51

Buvinic,, M., Das Gupta, M., \& Shemyakina, O. N. (2013). Armed conflict, gender and schooling. The World Bank Economic Review, 28(2), 311-319. https://doi.org/10.1093/ wber/1hto32

Contreras, M., Heilman, B., Barker, G., Singh, A., Verma, R., \& Bloomfield, J. (2012). Bridges to adulthood: Understanding the lifelong influence of men's childhood experiences of violence. International Center for Research on Women; Instituto Promundo. https:// resourcecentre.savethechildren.net/node/5991/pdf/5991.pdf

Ferris, E., \& Winthrop, R. (2010). Education and displacement: Assessing conditions for refugees and internally displaced persons affected by conflict. Biblioteca Digital Unesdoc. https:// unesdoc.unesco.org/ark:/48223/pfoooo190715

Gimenez, G., \& Barrado, B. (2020). Exposure to crime and academic achievement: A case study for Costa Rica using PISA data. Studies in Educational Evaluation, 65, 100867. https://doi.org/10.1016/j.stueduc.2020.100867

Gottwald, M. (2016). Peace in Colombia and solutions for its displaced people. Forced Migration Review, 1(52), 14-17.

Hattar-Pollara, M. (2019). Barriers to education of Syrian refugee girls in Jordan: Gender-based threats and challenges. Journal of Nursing Scholarship, 51(3), 241-251. https://doi.org/10.1111/jnu.12480

Ibáñez, A. M. (2006). La estabilización económica de la población desplazada. Fundación Ideas para la paz. https://www.files.ethz.ch/isn/152335/working_papers_3.pdf Ibáñez, A. M., \& Moya, A. (2010). Vulnerability of victims of civil conflicts: Empirical evidence for the displaced population in Colombia. World Development, 38(4), 647-663. https://doi.org/10.1016/j.worlddev.2009.11.015

Ibáñez, A. M., \& Querubín, P. (2004). Acceso a tierras y desplazamiento forzado en Colombia. Facultad de Economía, Universidad de Los Andes. https://bit.ly/zoqDBCY Internal Displacement Monitoring Centre. (2020). Global report on internal displacement. Autor. https://www.internal-displacement.org/global-report/grid2o2o/ 
Kadir, A., Shenoda, S., \& Goldhagen, J. (2019). Effects of armed conflict on child health and development: A systematic review. PloS one, 14(1), 1-37. https://doi.org/10.1371/ journal.pone.0210071

Kamal, M., \& Bener, A. (2009). Factors contributing to school failure among school children in very fast developing Arabian society. Oman Medical Journal, 24(3), 212-217.

Kecmanovic, M. (2012). The short-run effects of the Croatian war on education, employment, and earnings. Journal of Conflict Resolution, 57(6), 991-1010. https://doi.org/ $10.1177 / 0022002712454268$

Lei, Z., \& Lundberg, S. (2020). Vulnerable boys: Short-term and long-term gender differences in the impacts of adolescent disadvantage. IZA Institute of Labor Economics. http:// ftp.iza.org/dp12944.pdf

Lorence, J. (2014). Third-grade retention and reading achievement in Texas: A nine year panel study. Social Science Research, 48, 1-19. https://doi.org/10.1016/ j.ssresearch.2014.05.001

Mancini, M. A. (2020). A pilot study evaluating a school-based, trauma-focused intervention for immigrant and refugee youth. Child \& Adolescent Social Work Journal, 37 (3), 287-30o. https://doi.org/10.1007/s10560-019-00641-8

Manrique-Palacio, K. P., Zinke, L., \& Russo, A. R. (2018). Pisotón: un programa de desarrollo psicoafectivo, como alternativa para construir la paz. Revista Latinoamericana de Ciencias Sociales, Niñez y Juventud, 16(1), 131-148. https://dx.doi.org/ 10.11600/1692715x.16107

Ministerio de Salud y Protección Social \& Profamilia. (2015). Encuesta nacional de demografía y salud [National Demographic and Health Survey]. http://dhsprogram.com/ pubs/pdf/FR334/FR334.pdf

Mooney, E., \& French, C. (2005). Barriers and bridges: Access to education for internally displaced children. https://brook.gs/3eoHWRn

Moya, A., \& Carter, M. R. (2019). Violence and the formation of hopelessness: Evidence from internally displaced persons in Colombia. World Development, 113, 100-115. https://doi.org/10.1016/j.worlddev.2018.08.015

Munevar, S. M., Silva-Arias, A. C., \& Sarmiento-Espinel, J. A. (2019). Exposición al conflicto armado y logro académico en Colombia. Desarrollo y Sociedad, (83), 13-53. https://doi.org/10.13043/dys.83.1

Navarrete, E. L., Padrón, M., \& Silva-Arias, A. C. (2017). Jóvenes en situación de doble inactividad (laboral y educativa) en Colombia, en México y en Uruguay. https:// archivos.juridicas.unam.mx/www/bjv/libros/9/4316/9.pdf 
Needham, B. L., Crosnoe, R., \& Muller, C. (2004). Academic failure in secondary school: The inter-related role of health problems and educational context. Social Problems, 51(4), 569-586. https://doi.org/10.1525/sp.2004.51.4.569

Ordóñez, L. (2009). Evaluación de la desmovilización de niños y niñas ex combatientes en Colombia dentro del marco general del proceso de desarme [Tesis de maestría, Flacso]. Biblioteca digital de vanguardia para la investigación en Ciencias Sociales. http:// hdl.handle.net/10469/1074

Prada, A. (2016). Comprensión de la responsabilidad política de los actores armados en el conflicto interno colombiano: la masacre de El Salado 200o. Revista Latinoamericana de Ciencias Sociales, Niñez y Juventud, 14(2), 1537-1548.

Rodríguez, C., \& Sánchez, F. (2012). Armed conflict exposure, human capital investments, and child labor: Evidence from Colombia. Defence and Peace Economics, 23(2), 161-184. https://doi.org/10.1080/10242694.2011.597239

Rodríguez, J., Zaccarelli-Davoli, M., \& Pérez, R. (2006). Guía práctica de salud mental en situaciones de desastres. Pan American Health Organization. https://iris.paho.org/ handle/10665.2/2800

Save the Children. (2018). Migration and displacement of children in Latin America and the Caribbean. https://bit.ly/zoxDXrc

Schneider, S. (2020). Associations between childhood exposure to community violence, child maltreatment and school outcomes. Child Abuse \& Neglect, 104, 104473. https:// doi.org/10.1016/j.chiabu.2020.104473

Sutanuka, R., \& Prakarsh, S. (2016). Gender bias in education during conflict: Evidence from Assam. HiCN Working Papers 225. https://ideas.repec.org/p/hic/wpaper/225.html

Unidad para la Atención y Reparación Integral a las Víctimas. (2019). Registro Nacional de Información. https://cifras.unidadvictimas.gov.co/Home/General

United Nations Development Programme, \& World Health Organization. (2005). The Global Armed Violence Prevention Programme (AVPP): Phase I support for the development of a framework to address the impacts of armed violence on human security and development. https://bit.ly/2UoGwrS

United Nations Educational Scientific and Cultural Organization. (2011). The hidden crisis: armed conflict an education. https://bit.ly/3f8WzlI 